\title{
NOMOGRAMS FOR MORPHOMETRIC GRAVEL ANALYSIS
}

\author{
JOHN L. VAN GENDEREN \\ Fairey Surveys Limited, Maidenhead (Great Britain)
}

(Received October 10, 1975 ; revised and accepted May 26, 1976)

\begin{abstract}
Van Genderen, J.L., 1977. Nomograms for morphometric gravel analysis. Sediment. Geol., 17: 285-294.

Most methods of quantitative morphometric gravel analysis are very time consuming. To alleviate this situation, the author has developed three nomograms for plotting the Gailleux indices of roundness, flatness and dissymmetry. These nomograms enable results to be read off automatically in classes, so that the individual index values need not be ranked or grouped into classes separately, thereby allowing plotting without calculation. The nomograms are very versatile in that they are readily modified to suit individual requirements. The nomograms enable results to be obtained instantly in the field, and should prove useful to anyone using the Cailleux indices.
\end{abstract}

\section{INTRODUCTION}

A detailed study of footslopes carried out in southeast Spain involved the use of morphometric gravel analysis. This included the compilation of 600 histograms for the Cailleux index of roundness, and 600 histograms for the Cailleux index of flatness. Each histogram represented 100 rock fragments, for each of which the pebble parameters of length, breadth, thickness and minimum radius of curvature were measured.

The time that such an exercise would have taken using existing techniques is very great, if not prohibitive. This time element, in fact is one of the reasons why the technique of quantitative morphometric gravel analysis has not been used more widely in studies involving coarse surface materials. Whilst the actual measuring of the length, breadth, thickness, and minimum radius of curvature of the 100 pebbles, randomly selected at each site does not take long, especially if one uses a specially constructed chart for this purpose, the subsequent calculations and compilation of the histograms take a long time. If carried out in the field, the small computations necessary for the index of roundness, for example, for one sample of 100 rock fragments takes from one to one and a half hours. Even if done in the office using an electronic calculator, it takes $30-60 \mathrm{~min}$ to arive at the required histogram. 
Some workers use computer methods for such calculations. Griffiths and Ondrick (1969) performed their data recording in the field on Port-a-punch cards, and the computer analysis takes but a few seconds. Whilst it is realized that it would be a relatively simple matter to make a computer programme which would both determine the indices and display the results, this was not considered to be particularly desirable, as (a) the facilities are not always available, and (b) the need is normally for a rapid method which can be employed on the spot, so that any anomalies or significant results can immediately be examined in the field.

The writer's attempt to find a faster method of calculation and presentation, together with the solution of the nomograms are examined and explained after a brief discussion on morphometric gravel analysis.

\section{MORPHOMETRIC GRAVEL ANALYSIS}

The methods for morphometric analysis of pebbles, cobbles and boulders were introduced by Wadell (1932), Pettijohn (1936) and Krumbein (1941a, b). These, although extensively used by geologists in America, are rather intricate and time consuming if compared with the method proposed by Cailleux $(1945,1946-1947,1947,1952 a, b)$, which is used in European countries, especially for coarse materials (Mabesoone, 1959; Raynal and Nonn, 1968; Gregory and Cullingford, 1974).

The "Cailleux Indices" are indicated in Fig. 1. Not all of Cailleux's indices have been adopted without criticism. Tricart and Schaeffer (1950), Berthois (1950) and Mabesoone (1959) have reviewed and judged the indices on their merits. Poser and Hovermann (1952), experienced difficulties when using the flatness index. They observed that with decreasing $l$ (i.e. increasing flatness) and also with increasing $L$ (i.e. increasing slenderness) and providing $E$ (thickness) remained constant, the values of the index increased. This means that slender but not flat, and flat, but not slender pebbles may have the same

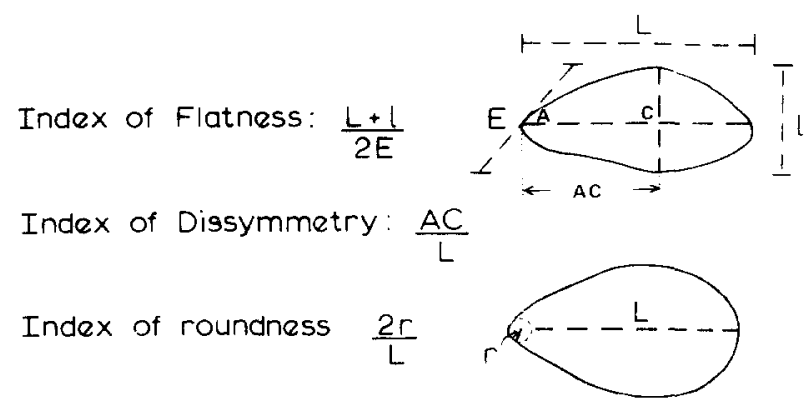

Fig. 1. Pebble parameters used for morphometric gravel analysis (after Cailleux).

$L=$ maximum length; $l=$ maximum width; $E=$ maximum thickness; $r=$ minimum radius of curvature; $A C=$ measure of dissymmetry. 
index value. To overcome this problem, Poser and Hovermann divided the Cailleux index of flatness into:

(1) Flatness $=l / E$

(2) Slenderness $=L / l$

since flatness and slenderness are two different shapes.

Some objections have also been raised against the use of the roundness index in its form of $2 r / L$, mainly because here, a slightly rounded, spherical pebble can have the same index value as a well-rounded ellipsoidal one. There is also a measurement problem here, for while it is relatively easy to measure the smallest radius of curvature using a grid with circles of various sizes, for sub-rounded and rounded pebbles, it is more difficult to measure angular and sub-angular fragments. The method used by the writer (Fig. 2) was that for any rock fragment, the minimum radius was taken as $r^{1}$, where $r^{1}$ and $r^{2}$ are equal (i.e. 0 is the centre of a circle passing through $X, Y$ and $Z$; $2 r$ is then equal to the distance $X Z$ ). Using this method of equal radii to determine $2 r$, both a truly angular rock fragment (Fig. 2A), and a subrounded one (Fig. 2B), could have the same $2 r$ value. This therefore amounts to a similar degree of error as occurs in soil particle size analysis using sieves with a square mesh, only there the error in diameter can be in three dimensions, while here it is only in two. It may in fact be better to use angles (in degrees or percent) instead of radius of curvature (in millimeters) as a means of measuring the index of roundness, as with footslope deposits, the fragments are more angular than rounded. While radius of curvature may be easily measured on fluvial deposits, angle of curvature is more readily measured on footslope deposits.

Richter $(1954,1955)$ took into consideration not only the smallest radius of curvature, but also the rounding with the greatest radius although this was often infinity. Keunen $(1955,1956$ and 1958) in his experimental studies on the roundness of pebbles by different agents found that $l$ has greater importance than $L$, because a long ellipsoidal pebble will roll around its $l$-axis, and not around its longest axis. Thus he proposed the use of $2 r / l$ instead of $2 r / L$. Another alternative has been proposed by Kaiser (1956), who recommended using $4 r /(L+l)$ for the index of roundness, thereby considering to a certain degree, the shape of the pebble.

Van Andel et al. (1954) compared the American and French methods as
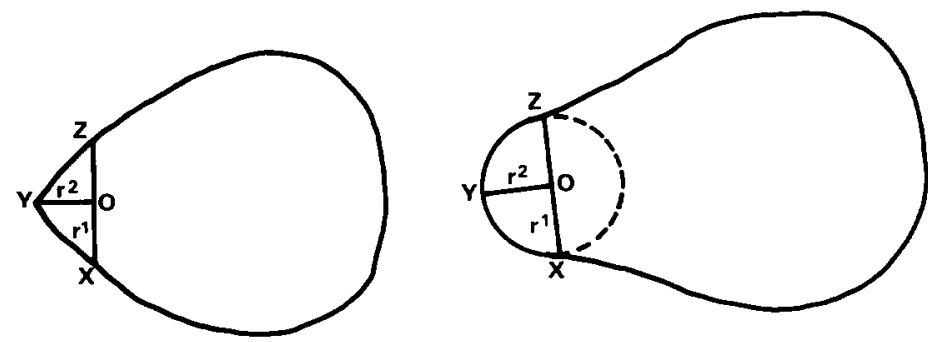

Fig. 2. Measurement of $2 r$. 
well as studying the Zingg (1935) method on samples of marine gravels in The Netherlands. Although they preferred the Krumbein ratio, they concluded that the Cailleux index is easier to obtain and much more widely used. Brock (1974) compares various shape indices, and concludes that several are unreliable for discriminatory purposes. It is not the purpose of this paper to appraise the value of coarse sediment morphometry as a tool for environment discrimination, but simply to provide a faster method of carrying such methods out. The reader is referred to Brock's paper for his discussion on the problems surrounding the reliability of coarse sediment morphometry for diagnostic purposes.

Whilst being aware of the alternatives to the Cailleux indices, the author has adopted the Cailleux method in his work on footslope deposits. One of the factors influencing this choice was that by using the Cailleux indices, one can compare directly, the results obtained with those of other workers in recent years (Raynal and Nonn, 1968; Dobbins and Folk, 1970; Gregory and Cullingford, 1974; Glover, 1975).

\section{THE NOMOGRAMS}

The three nomograms for the determination of the indices of roundness, flatness and dissymmetry depicted in Fig. 3, 4 and 5, allow one to convert the raw data into the final histograms in less than ten minutes for each histogram. Not only are no calculations needed, but the results are automatically read off in classes, so that the individual index values need not be ranked or grouped into classes separately. The class interval can be easily varied to meet each worker's own requirements, by simply shifting the vertical class lines drawn on the histograms.

The three nomograms, devised and tested by the writer, were developed as follows:

Index of roundness (Fig. 3): $I_{\mathrm{r}}=2 r / L$

The minimum value possible is zero. The values of the index of roundness $\left(I_{\mathrm{r}}\right)$ for pebbles of $20 \mathrm{~mm}$ length (the minimum length of pebble used), were then calculated for $2 r$ values from $0 \mathrm{~mm}$ to $26 \mathrm{~mm}$, and plotted on the graph. The same was done for all lengths from $20 \mathrm{~mm}$ to $120 \mathrm{~mm}$ (the maximum length of pebble used). The scale can easily be extended in the $Y$ direction if very rounded pebbles are encountered, and additional $L$ lines can be added if pebbles smaller than $20 \mathrm{~mm}$ or longer than $120 \mathrm{~mm}$ are required. One now simply reads off the values $2 r$ and $L$, and the point where these intersect, indicates the value of the actual index of roundness along the $X$-axis, as well as the arbitrary class to which it belongs, as shown by the vertical class lines. As mentioned above, these class lines as depicted on the nomogram, can easily be changed or shifted along the $X$-axis to suit one's own requirement. 


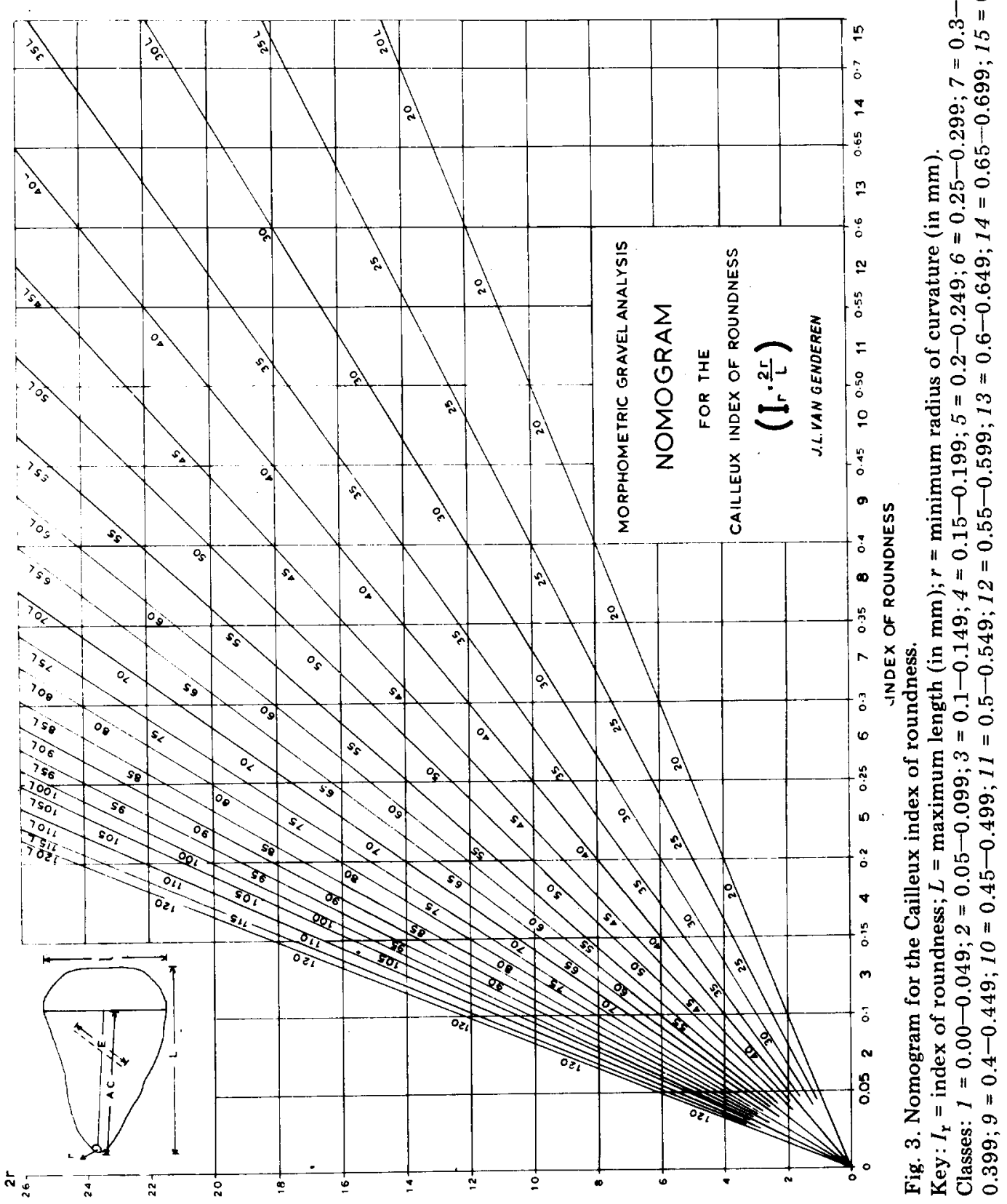




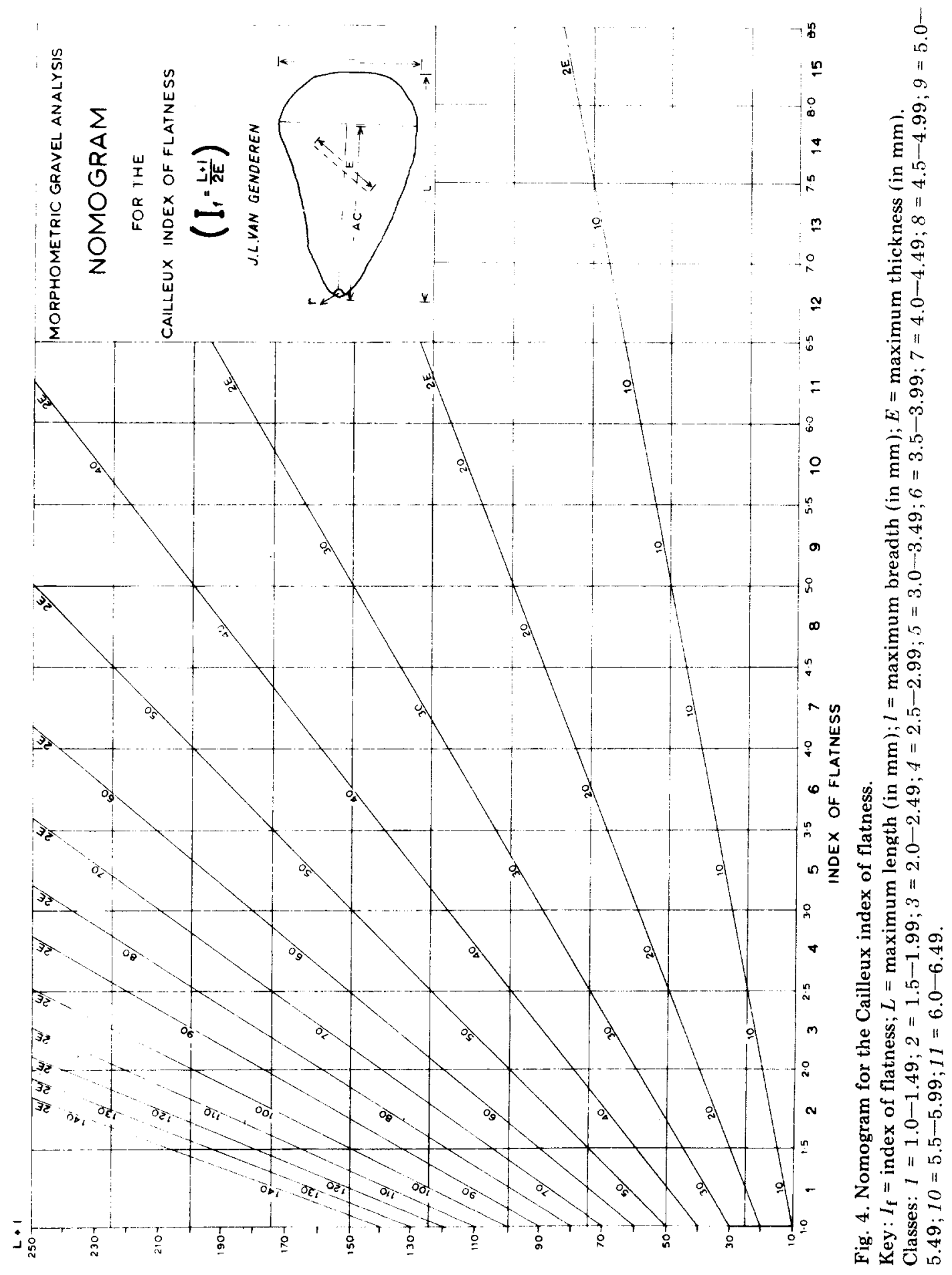




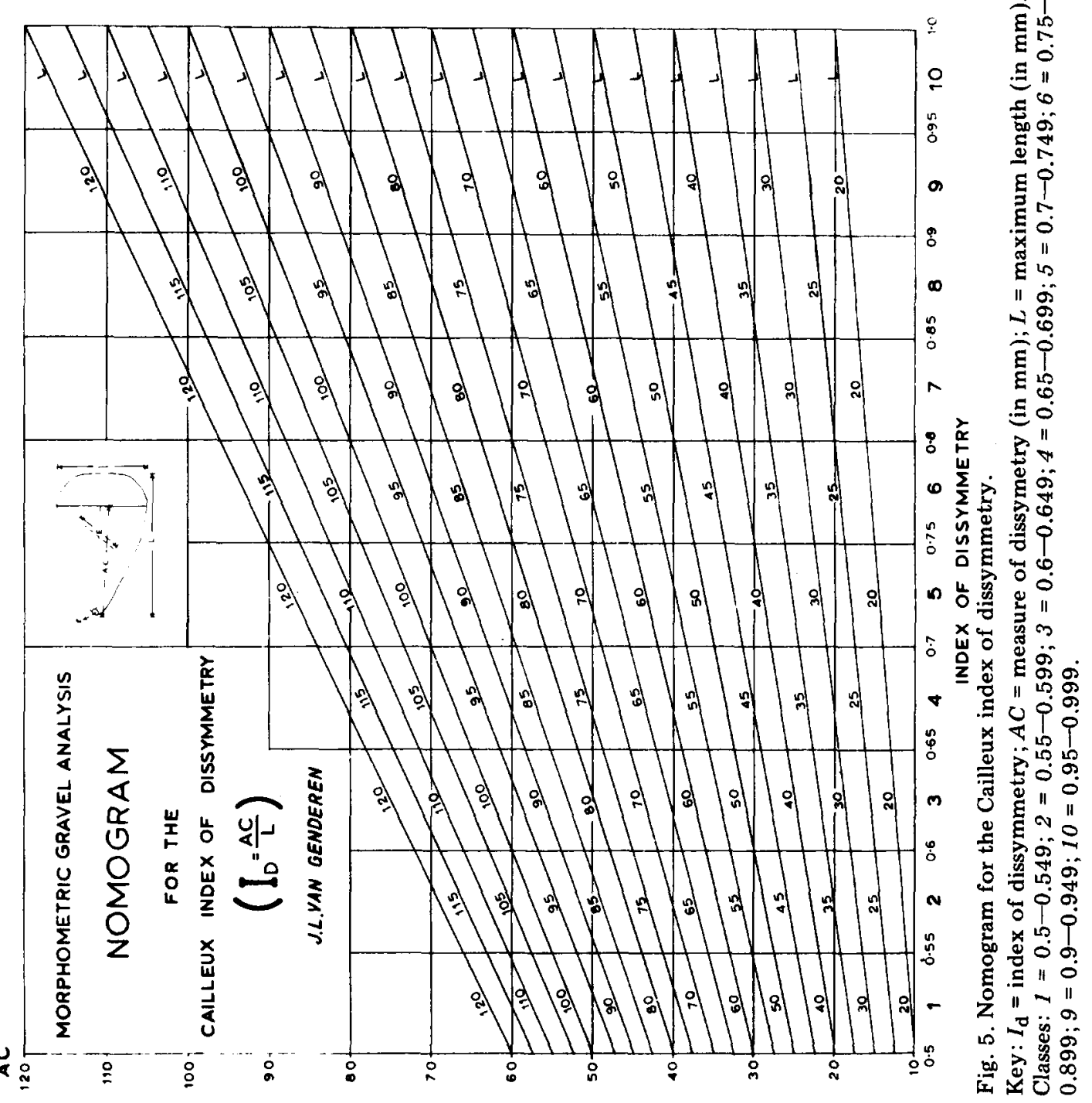


Index of flatness (Fig. 4): $I_{\mathrm{f}}=L+l / 2 E$

As the minimum pebble length considered was $20 \mathrm{~mm}$ and the maximum $120 \mathrm{~mm}, L+l$ must always be between 20 and $240 \mathrm{~mm}$. These values of $L+$ $l$ were marked on the $Y$-axis, and the index of flatness on the $X$-axis. As $L+$ $l$ is always larger than $2 E$ (by definition) the index of flatness can never be less than unity. This index was then plotted for all pebble sizes with $2 E$ values between 10 and $140 \mathrm{~mm}$. Again, the $Y$-axis can be extended if it is necessary to measure larger pebbles, and extra $2 E$ values can be added to the nomogram. One now simply reads the actual index of flatness value indicated on the $X$-axis, as well as the class to which the pebble belongs, from the intersection of the $L+l$ and $2 E$ values.

Index of dissymmetry (Fig. 5): $I_{\mathrm{d}}=A C / L$

A similar procedure to that described above was employed to construct the nomogram for the index of dissymmetry with the $A C$ values plotted on the $Y$-axis, and the index of dissymmetry on the $X$-axis. The values were then plotted for pebble sizes from $20 \mathrm{~mm}$ to $120 \mathrm{~mm}$. As the length $A C$, by definition (see Fig. 1) is always less than $L$, the index of dissymmetry values plotted on the $X$-axis can never exceed unity. To obtain the index of dissymmetry value, the intersection of the $A C$ value with the $L$ value is projected onto the $X$-axis to determine both the index and the class category. As with the previous nomograms, the scales can be extended to cope with larger pebbles.

\section{SUMMARY}

To expedite the calculation of the Cailleux indices, three nomograms which are simple to construct and use have been devised and described in this paper. They increase greatly the speed with which quantitative morphometric gravel analysis can be carried out. The system is very versatile, being able to cope not only with a large particle size range, but also with two methods of subsequent analysis. This is so because the nomograms lend themselves to both visual and quantitative analysis of the data; visual in that class lines can be drawn in to facilitate the construction of histograms showing the distribution of the pebble shapes in a sample, and quantitative in that the exact individual index values for each pebble at a site are obtained which can be subjected to a variety of statistical testing techniques. Whilst most studies in Europe have used the histogram method for analysis of coarse footslope deposits, the use of these nomograms, enable rigorous statistical analysis to show the sources of variation, test data before accepting anomalies, and demonstrate that they are not simply "noise" (Griffiths, 1967; Brock, 1974). Thus the use of the three nomograms for the Cailleux indices 
will enable more rapid and reliable morphometric gravel analysis of coarse materials to be carried out.

\section{ACKNOWLEDGEMENT}

The author gracefully acknowledges the financial assistance of the University of Sheffield's Research Fund Committee which enabled the field work to be carried out for this project, which was initiated whilst the writer was a staff member of the Department of Geography, University of Sheffield.

\section{REFERENCES}

Berthois, L., 1950. Méthode de l'étude des galets. Applications à l'étude de l'évolution des galets marins actuels. Rev. Géomorphol. Dyn., 1: 199-225.

Brock, E.J., 1974. Coarse sediment morphometry: a comparative study. J. Sediment. Petrol., 44: 663-672.

Cailleux, A., 1945, Disidection des galets marins et fluviatiles. Bull. Soc. Geol. Fr., 6ieme Ser., 40: 375-404.

Cailleux, A., 1946-1947. Granulométrie des formations à galets. Sess. extra. Soc. Belge Geol. Paleontol. Hydrol., pp. 91-114.

Cailleux, A., 1947. L'indice d'émoussé: définitions et première application. C.R. Somm. Seances Soc. Géol. Fr., No. 13: pp. 250-252.

Cailleux, A., 1952a. Morphoskopische Analyse der Geschiebe und Sandkorner und ihre Bedeutung für die Paläoklimatologie. Geol. Rundsch., 40:11-19.

Cailleux, A., 1952b. L'indice démoussé des grains de sable et grès. Rev. Géomorphol. Dyn., 3: 78-87.

Coque, R., 1962. La Tunisie présaharienne: étude géomorphologique. Thesis, Univ. Paris.

Dobkins, J.E. and Folk, R.L., 1970. Shape development on Thahiti-Nui. J. Sediment. Petrol., 40: 1167-1203.

Glover, B.K., 1975. A morphometric analysis of terrace gravels in Santa Ynez basin, Santa Barbara Country, California. Sediment. Geol., 13: 109-124.

Gregory, K.J. and Cullingford, R.B., 1974. Lateral variations in pebble shape in northwest Yorkshire. Sediment. Geol., 12: 237-248.

Griffiths, J.C., 1967. Scientific Method in the Analysis of Sediments. McGraw, New York, N.Y., 508 pp.

Griffiths, J.C. and Ondrick, C.W., 1969. Sampling a Geological Population. Computer Contribution 30, State Geological Survey, Univ. of Kansas, Lawrence, 53 pp.

Kaiser, K., 1956. Geologische Untersuchungen über die Hauptterrasse in der Niederrheinischen Bucht. Sonderveröff. Geol. Inst. Köln, 1:68 pp.

Keunen, P.H., 1955. Experimental abrasian of pebbles, 1. Wet sand blasting. Leidse Geol. Meded., 20: 142-147.

Keunen, P.H., 1956. Experimental abrasion of pebbles, 2. Rolling by current. J. Geol., $64: 336-368$.

Keunen, P.H., 1968. Some experiments on fluviatile rounding. Proc. K. Ned. Akad. Wet., Sect. B, Ser. B, No. 61 : pp. 152-157.

Krumbein, W.C., 1941a. The effects of abrasion on the size, shape and roundness of rock fragments. J. Geol., 49: 482-520.

Krumbein, W.C., 1941b. Measurement and geological significance of shape and roundness of sedimentary particles. J. Sediment. Petrol., 11: 64-72.

Mabesoone, J.M., 1959. Tertiary and Quaternary sedimentation in a part of the Duero 
Basin, Palencia, Spain. Leidse Geol. Meded., 24: 314-380.

Pettijohn, F.J., 1936. Determination and calculation of sphericity values of pebbles. J. Sediment. Petrol., 6: 154-151.

Poser, H. and Hovermann, J., 1952. Beitrage zur morphometrischen und morphologischen Schotteranalyse. Abh. Braunschw. Wiss. Ges., 4: 12-36.

Raynal, R. and Nonn, H., 1968. Glacis étages et formations quaternaires de Galice orientale et de Leon: quelques observations et données nouvelles. (Rev. Geomorphol. Dyn., 18 (3): $97-117$.

Richter, K., 1954. Geröllmorphometrische Studien in den Mittelterrassenschottern bei Gronau und der Leine. Eiszeitalter Gegenw., 4/5: 216-220.

Richter, K., 1955. Geröllanalytische Untersuchung des Pleistozans im unteren Emsgebiet mit Vergleichen zum Sylter Kaolinsand. Geol. Jahrb., 71: 449-460.

Tricart, J. and Schaeffer, R., 1950. L'indice d'émoussé des galets, moyen d'étude des systèmes d'érosion. Rev. Géomorphol. Dyn., 1 (4).

Van Andel, T.H., Wiggers, A.J. and Maarleveld, G., 1954. Roundness and shape of marine gravels from Urk, a comparison of several methods of investigation. J. Sediment Petrol., 24: 100-116.

Wadell, H., 1932. Volume, shape and roundness of rock particles. J. Geol., 40: 443-351.

Wentworth, C.K., 1933. The shape of rock particles: a discussion. J. Geol., 41 : 306-330.

Zingg, T., 1935. Beitrag zur Schotteranalyse. Schweiz. Mineral. Petrogr. Mitt., 15: 39140 . 